\title{
High diversity of Rhodobacterales in the subarctic North Atlantic Ocean and gene transfer agent protein expression in isolated strains
}

\author{
Yunyun Fu ${ }^{1, *}$, Dawne M. MacLeod ${ }^{1, *}$, Richard B. Rivkin ${ }^{2}$, Feng Chen ${ }^{3}$, \\ Alison Buchan ${ }^{4}$ Andrew S. Lang ${ }^{1, * *}$ \\ ${ }^{1}$ Department of Biology, Memorial University of Newfoundland, 232 Elizabeth Ave., St. John's, \\ Newfoundland A1B 3X9, Canada \\ ${ }^{2}$ Ocean Sciences Centre, Memorial University of Newfoundland, Marine Lab Road, St. John's, \\ Newfoundland A1C 5S7, Canada \\ ${ }^{3}$ Center of Marine Biotechnology, University of Maryland Biotechnology Institute, 236-701 East Pratt St., \\ Baltimore, Maryland 21202, USA \\ ${ }^{4}$ Department of Microbiology, University of Tennessee, M409 Walters Life Sciences, Knoxville, Tennessee 37914, USA
}

\begin{abstract}
Genes encoding gene transfer agent (GTA) particles are well conserved in bacteria of the order Rhodobacterales. Members of this order are abundant in diverse marine environments, frequently accounting for as much as $25 \%$ of the total bacterial community. Conservation of the genes encoding GTAs allows their use as diagnostic markers of Rhodobacterales in biogeographical studies. The first survey of the diversity of Rhodobacterales based on the GTA major capsid gene was conducted in a warm temperate estuarine ecosystem, the Chesapeake Bay, but the biogeography of Rhodobacterales has not been explored extensively. This study investigates Rhodobacterales diversity in the cold subarctic water near Newfoundland, Canada. Our results suggest that the subarctic region of the North Atlantic contains diverse Rhodobacterales communities in both winter and summer, and that the diversity of the Rhodobacterales community in the summer Newfoundland coastal water is higher than that found in the Chesapeake Bay, in either the summer or winter. Approximately one-third of GTA sequences retrieved from the subarctic waters were most closely related to those from bacteria isolated from sea ice or cold regions. Distinguishable diversity patterns were found between the temperate and subarctic waters, providing further support for niche adaptation of specific Rhodobacterales members to unique environments. We also demonstrate that a number of Rhodobacterales strains, from both the subarctic and temperate locations, express the GTA major capsid protein. This provides robust evidence that the widespread conservation of GTA genes in the Rhodobacterales may result in the production of functionally similar and active GTA systems in these bacteria in different environments.
\end{abstract}

KEY WORDS: Rhodobacterales · Gene transfer agent · GTA · Major capsid protein

\section{INTRODUCTION}

Estimates in marine microbial populations suggest members of the $\alpha$-proteobacterial order Rhodobacterales, specifically the Roseobacter clade, can comprise upwards of $25 \%$ of total marine bacterioplank- ton (Buchan et al. 2005). All complete Rhodobacterales genome sequences contain gene transfer agent (GTA) gene clusters (Lang \& Beatty 2007, Biers et al. 2008). GTAs are bacteriophage-like particles that package and transfer genomic DNA between bacterial cells in a process analogous to transduction. 
GTAs are distinguished from transducing phages in several ways, including the apparently random and obligate packaging of fragments of the producing cell's genome, and the fact that the size of DNA packaged in the particles is insufficient to encode the full GTA structure (Lang \& Beatty 2007, Stanton 2007). This mechanism of genetic exchange has been identified in diverse prokaryotic species: the purple non-sulfur $\alpha$-proteobacterium Rhodobacter capsulatus (Marrs 1974), the sulfate-reducing $\delta$-proteobacterium Desulfovibrio desulfuricans (Rapp \& Wall 1987), the spirochete Brachyspira hyodysenteriae (Humphrey et al. 1997), the methanogenic archaeon Methanococcus voltae (Bertani 1999), and the marine Rhodobacterales bacterium Ruegeria (formerly Silicibacter) pomeroyi (Biers et al. 2008). With the exception of the $R$. pomeroyi GTA (Biers et al. 2008), all of these particles structurally resemble tailed phages (reviewed in Stanton 2007).

The role of GTAs in natural environments is not yet understood, but they exist in the above-mentioned (and presumably other) phylogenetically diverse prokaryotes, suggesting this mode of DNA transfer may be important in shaping some microbial genomes and communities. An outcome of GTA production for the producing species is homologous recombination. Therefore GTA activity could provide benefits to the producing species as a whole (Vos 2009), even if it is detrimental to the individual producing cell that presumably must lyse to allow GTA release. The release of GTAs is known to occur by lysis only in Brachyspira hyodysenteriae (Humphrey et al. 1997, Matson et al. 2005), but it is anticipated that cell lysis is the likely mechanism of release for all GTAs because there is no known release of tailed phage particles from cells other than through lysis.

The Rhodobacter capsulatus GTA (RcGTA) gene cluster comprises 16 open reading frames (ORFs) in $\sim 14 \mathrm{~kb}$ on the bacterial chromosome (Lang \& Beatty 2000, Lang \& Beatty 2007). Several of these ORFs have recognizable homology to known bacteriophage genes, such that the cluster appears to be an isolated head- and tail-encoding unit. Of these $16 \mathrm{ORFs}_{1} 3$ are particularly well conserved between different species (Lang et al. 2002): g2, predicted to encode the large terminase protein, 95 , encoding the major capsid protein, and $g 9$, predicted to encode the major tail protein (Lang \& Beatty 2000, Lang \& Beatty 2007). Due to the conservation of GTA genes in the Rhodobacterales order, the GTA major capsid protein-encoding gene, g5, has been used as a marker to estimate Rhodobacterales diversity in estuarine microbial communities (Zhao et al. 2009). This work demonstrated that there was a distinct temporal and spatial pattern of Rhodobacterales in the Chesapeake
Bay and that g5 sequence diversity was higher in these natural communities than appreciated from previous isolates.

We have exploited the GTA gene conservation to explore the diversity of Rhodobacterales in microbial communities in the subarctic western North Atlantic Ocean. The results presented here demonstrate that the cold productive subarctic waters of coastal Newfoundland (Canada) harbor a remarkably diverse collection of Rhodobacterales, and approximately onethird of the GTA gene sequences retrieved from these waters were most similar to those from bacteria isolated from sea ice or cold regions. The propensity of the characterized representatives of ecologically important Rhodobacterales bacteria to display the genetic potential for production of GTAs warrants further investigation of this property. Therefore, we have also cultured several strains from this coastal environment and demonstrated GTA capsid protein expression amongst these, as well as in strains recovered from the Chesapeake Bay. These findings show that, not only the genetic potential for GTA production, but also the expression of the GTA capsid protein is widespread, both taxonomically and biogeographically, among members of the Rhodobacterales. This research provides further evidence that GTA-mediated gene transfer could be an important phenomenon in natural microbial communities.

\section{MATERIALS AND METHODS}

Sample collection. Microbial communities were collected onto $0.2 \mu \mathrm{m}$ polycarbonate filters (Millipore) from $500 \mathrm{ml}$ surface water samples collected at Tapper's Cove $\left(47^{\circ} 39^{\prime} 54^{\prime \prime} \mathrm{N}, 52^{\circ} 43^{\prime} 38^{\prime \prime} \mathrm{W}\right)$ on July 24, 2007, and at Logy Bay $\left(47^{\circ} 38^{\prime} 14^{\prime \prime} \mathrm{N}, 52^{\circ} 39^{\prime} 36^{\prime \prime} \mathrm{W}\right)$ on December 11, 2008. These are adjacent locations that experience very similar climate and hydrographic forcing, and the inshore branch of the Labrador Current influences both bays. DNA was extracted from the filters as previously described (Kan et al. 2006). Filters were thawed and each one was combined with $2 \mathrm{ml}$ pre-lysis buffer $(0.1 \mathrm{M}$ Tris-HCL; $0.1 \mathrm{M}$ EDTA; $0.8 \mathrm{M}$ sucrose; $\mathrm{pH} 8$ ) and $10 \mu \mathrm{l}$ lysozyme (200 $\left.\mu \mathrm{g} \mathrm{ml}^{-1}\right)$ and incubated at $37^{\circ} \mathrm{C}$ for $30 \mathrm{~min}$. This incubation was followed by addition of $200 \mu \mathrm{l}$ of $10 \%$ (w/v) cetyltrimethylammonium bromide (CTAB) in $1.4 \mathrm{M} \mathrm{NaCl}$ and incubation at $65^{\circ} \mathrm{C}$ for $30 \mathrm{~min}$. Samples were then sequentially extracted with phenol-chloroform-isoamyl alcohol (25:24:1) and chloroform-isoamyl alcohol (24:1), followed by isopropanol precipitation. Following a wash with $70 \%$ ethanol, the pellets were air-dried and dissolved in $200 \mu \mathrm{l}$ Tris-EDTA (TE) buffer. 
Water samples for enumerating bacterial abundance were fixed with $0.2 \mu \mathrm{m}$ filtered formaldehyde (final concentration $3.7 \%$ ) and filtered onto $0.2 \mu \mathrm{m}$ polycarbonate membrane filters. Cells were stained with $1 \mu \mathrm{g} \mathrm{ml}^{-1}$ DAPI (4',6-diamidino-2-phenylindole) and counted by epifluorescence microscopy at $1250 \times$ magnification using UV light excitation. For each sample, at least 1000 cells were enumerated.

PCR amplification, cloning and sequencing of GTA g5 genes. Degenerate primers for amplification of GTA g5 genes (encoding the major capsid protein) described previously (Zhao et al. 2009) were used in the present study: MCP-109F, 5'-GGC TAY CTG GTS GAT CCS CAR AC-3' and MCP-368R, 5'-TAG AAC AGS ACR TGS GGY TTK GC-3'. Target DNA was amplified in a single round of PCR in $25 \mu \mathrm{l}$ volumes containing $0.5 \mu \mathrm{M}$ of each primer, $3 \%$ DMSO (v/v), $200 \mu \mathrm{M}$ dNTPs, $1 \times$ Phusion Buffer (NEB), and $0.02 \mathrm{U}$ $\mathrm{\mu l}^{-1}$ of Phusion Hot Start polymerase (NEB). Thermocycling conditions were as follows: $30 \mathrm{~s}$ at $98^{\circ} \mathrm{C}$, followed by 35 cycles of $98^{\circ} \mathrm{C}$ for $10 \mathrm{~s}, 60^{\circ} \mathrm{C}$ for $30 \mathrm{~s}$, and $72^{\circ} \mathrm{C}$ for $30 \mathrm{~s}$, and a final extension step at $72^{\circ} \mathrm{C}$ for 7 min. PCR products were purified using a Qiaquick PCR Clean-up kit (Qiagen) and 3' adenine overhangs were added by incubation with $1 \mathrm{U}$ of Taq polymerase (NEB) at $72^{\circ} \mathrm{C}$ for $10 \mathrm{~min}$ in $1 \times$ Taq buffer (NEB). PCR products were cloned into the pGEM-T Easy Vector System (Promega) according to the manufacturer's recommendations, and clones containing appropriately sized inserts were sequenced at either the Genomics and Proteomics Facility at Memorial University (St. John's, Canada) or the Centre for Applied Genomics (Toronto, Canada) using the M13 primers that bind to the cloning vector.

Isolation and characterization of Rhodobacterales. A sub-sample of the seawater collected at Logy Bay on December 11, 2008 for community analysis (see 'Sample collection') was used for isolation of Rhodobacterales bacteria. Seawater was spread directly onto sterile Petri plates that contained dimethylsulfonyl propionate (DMSP) as the sole carbon source. This enrichment is designed to select for bacteria of the Rhodobacterales order, which often display the ability to use DMSP as a sole carbon and energy source (Buchan et al. 2005, Moran et al. 2007, Curson et al. 2008). The medium contained $150 \mu \mathrm{M} \mathrm{K}_{2} \mathrm{HPO}_{4}, 5 \mathrm{mM}$ $\mathrm{NH}_{4} \mathrm{Cl}, 500 \mu \mathrm{M}$ DMSP (Research Plus), vitamins, iron, and trace metals (Budinoff \& Hollibaugh 2007) in $0.22 \mu \mathrm{m}$-filtered seawater, and was solidified with $1 \%$ (w/v) noble agar. The plates were incubated at $20^{\circ} \mathrm{C}$ in the dark for 2 to $4 \mathrm{~d}$ until colonies appeared, and colonies were restreaked on DMSP plates. Individual colonies on these second DMSP plates were then replated and maintained on a complex medium (YTSS; $4 \mathrm{~g} \mathrm{l}^{-1}$ tryptone, $2.5 \mathrm{~g} \mathrm{l}^{-1}$ yeast extract, $15 \mathrm{~g} \mathrm{l}^{-1}$ sea salts;
Sigma-Aldrich). Each culture was then grown in liquid broth at $25^{\circ} \mathrm{C}$ for $1 \mathrm{~d}$ and DNA was extracted using the Puregene DNA Purification kit (Qiagen). The DNA from these isolates was used as templates for PCR with the $g 5$ primers (Zhao et al. 2009) as described in the previous section, purified and directly sequenced using the $g 5$ primers. The primers $27 \mathrm{~F}$ (5'-AGA GTT TGA TCM TGG CTC AG-3') (Giovannoni 1991) and Roseo536R (5'-CAA CGC TAA CCC CCT CCG-3') (Brinkmeyer et al. 2000) were used to amplify a $\sim 500 \mathrm{bp}$ region of the $16 \mathrm{~S}$ rRNA gene. The $16 \mathrm{~S}$ rDNA $\mathrm{PCR}$ reaction components were the same as for the $g 5$ reactions with the following thermocycling conditions: $30 \mathrm{~s}$ at $98^{\circ} \mathrm{C}$, followed by 35 cycles of $98^{\circ} \mathrm{C}$ for $10 \mathrm{~s}$, $58^{\circ} \mathrm{C}$ for $30 \mathrm{~s}$, and $72^{\circ} \mathrm{C}$ for $30 \mathrm{~s}$, and a final extension step at $72^{\circ} \mathrm{C}$ for $7 \mathrm{~min}$. Resulting PCR products were purified as described above and sequenced using these same $16 \mathrm{~S}$ primers. If this sequence identified the isolate as a member of the Rhodobacterales, the nearly complete 16S rRNA gene was amplified and sequenced using the primers $27 \mathrm{~F}$ and $1522 \mathrm{R}$ (5'-AAG GAG GTG ATC CAN CCR CA-3') (Giovannoni 1991). The PCR reaction components and thermocycling conditions were as described above with the extension step increased to $60 \mathrm{~s}$.

Sequence analyses. Sequences were edited to remove vector and primer sequences and aligned with Geneious v.3.8.5 (Biomatters). Sequences were assigned to operational taxonomic units (OTUs), within each sample library, using $97 \%$ identity as the criterion, as conducted previously (Zhao et al. 2009). The proportion of sequence diversity that had been discovered within each clone library was estimated by calculation of the percent coverage $(C)$ using the formula $C=1-(N / n) \times 100$, where $N$ is the number of unique sequences (i.e. those found only once in that sample), and $n$ is the total number of clones sequenced (Ravenschlag et al. 1999). The Shannon diversity index $\left(H^{\prime}\right)$ was calculated for the samples based on the OTU detection frequencies using the PAST software package (Hammer et al. 2001). Rarefaction analysis of each sample was conducted using Analytical Rarefaction v1.4 (www.uga.edu/strata/software/Software.html) to assess what proportion of the sample diversity (at least the portion that was successfully amplified) had been accounted for.

For phylogenetic analyses, alignments of $16 \mathrm{~S}$ rDNA sequences were performed using ClustalW within the program MEGA4 (Tamura et al. 2007), evolutionary distances were computed using the Maximum Composite Likelihood method (Tamura et al. 2004), and the evolutionary pattern was inferred by the NeighborJoining method (Saitou \& Nei 1987) using the pair-wise deletion of gaps option. A similar approach was used for analysis of the $g 5$ sequences; however, these 
nucleotide sequences were aligned according to the corresponding aligned amino acid sequences. Phylogenetic analyses were conducted for the environmental sequences reported here, sequences from the Chesapeake Bay (Zhao et al. 2009), and sequences from complete Rhodobacterales genomes that were available in GenBank. Accession numbers for previously published sequences are provided in Table S1, Supplement 1 (at www.int-res.com/articles/suppl/ a059p283_app.pdf). The g5 clone OTU sequences described in the present study have been submitted to GenBank and assigned accession numbers FJ872412 to FJ872476. Sequences from the isolates described in this work have been submitted to GenBank and assigned accession numbers GQ433706 to GQ433715.

Predicted molecular weights of capsid proteins were calculated based on the amino acid sequences using Geneious v.3.8.5 (Biomatters).

Western blotting. The control Rhodobacter capsulatus cultures were grown photosynthetically in YPS medium (Wall et al. 1975). R. capsulatus SB1003 (Yen \& Marrs 1976) is a GTA-producing strain and $R$. capsulatus A1 does not produce the GTA capsid protein due to a Tn5 insertion in the $g 5$ gene (J. T. Beatty pers. comm.). The Roseobacter strains were grown in liquid YTSS broth at $25^{\circ} \mathrm{C}$ for $3 \mathrm{~d}$. For cell samples, cells were pelleted by centrifugation at $17000 \mathrm{~g}$ for $2 \mathrm{~min}$, the medium was removed and the cells were resuspended in an equal volume of TE buffer. For supernatant samples, cells were removed by 2 rounds of centrifugation at $17000 \mathrm{~g}$ for $2 \mathrm{~min}$, with a sub-sample of the supernatant removed to a new tube after each centrifugation step. Two volumes of the cells or final culture supernatant were mixed with 1 volume $3 \times$ sodium dodecyl sulfate polyacrylamide gel electrophoresis (SDSPAGE) sample buffer (NEB) and heated to $98^{\circ} \mathrm{C}$ for $5 \mathrm{~min}$. The samples were subjected to SDS-PAGE on $10 \%$ polyacrylamide gels and transferred to a nitrocellulose membrane. The membrane was blocked with $5 \%(\mathrm{w} / \mathrm{v})$ skim milk in Tris-buffered saline Tween-20 (TBST) (20 mM Tris and $137 \mathrm{mM} \mathrm{NaCl}, \mathrm{pH} 7.5 ; 0.1 \%$ [v/v] Tween 20) and then incubated with primary antibody against the Rhodobacterales GTA major capsid protein (AS08 365; Agrisera AB) in TBST at $4^{\circ} \mathrm{C}$ overnight. After washing, the membrane was incubated with peroxidase-conjugated goat anti-rabbit IgG (Santa Cruz Biotechnology), and specific bands were detected by enhanced chemiluminescence with the SuperSignal West Femto Reagent (Pierce Biotechnology).

The antibody targeting the Rhodobacterales GTA major capsid protein is a polyclonal antibody that was raised against a synthetic peptide corresponding to a region of the GTA major capsid protein that is conserved at $>90 \%$ identity in all currently available Rhodobacterales sequences (Agrisera AB). An anti- body neutralization experiment was used to confirm that we were detecting bands specifically recognized by the anti-GTA primary antibodies. For the antibody neutralization experiment, the primary antibody was incubated with an approximately 100 -fold molar excess of the immunizing peptide in TBST for $2 \mathrm{~h}$ at room temperature. The control antibody (non-neutralized) was similarly pre-incubated in TBST for $2 \mathrm{~h}$, but without added peptide. The 2 antibody solutions were added to duplicate membranes with assorted Rhodobacterales strains/species.

\section{RESULTS AND DISCUSSION}

\section{High diversity of Rhodobacterales in the western North Atlantic Ocean}

We analyzed GTA g5 clone libraries generated from 2 coastal western North Atlantic Ocean surface water samples, one collected in summer and one collected in winter. The sequencing of 172 clones from the 2 libraries, 127 from the summer and 45 from the winter, led to the discovery of a diverse collection of Rhodobacterales communities in the sub-arctic water near Newfoundland. Fifty-nine OTUs were defined as sequences sharing $\geq 97 \%$ nucleotide identity. Of these 59 OTUs, 49 were found only in the summer sample, 5 were found only in the winter sample and 5 were found in both. There is a wide range of homology between the OTUs, with percent nucleotide identities ranging from 44 to $97 \%$, but the vast majority are between 50 and $70 \%$ identical (Supplement 2 at www.int-res.com/ articles/suppl/a059p283_app.xls). Pair-wise comparisons of all Rhodobacterales (partial) g5 sequences show that the most dissimilar are 53 and $42 \%$ identical at the protein and nucleotide levels, respectively. It is possible that the value of $97 \%$ identity is not a meaningful measure for these gene sequences, as we know little about the relationship between sequence variation and function for this gene. However, when the cutoff is reduced to $90 \%$, significant gene diversity is still evident (48 total OTUs across both samples).

The summer microbial community had a more diverse population of Rhodobacterales compared with the winter (Table 1, Fig. S1 in Supplement 1 at www. int-res.com/articles/suppl/a059p283_app.pdf). Furthermore, the Shannon index in the summer Newfoundland coastal water $\left(H^{\prime}=3.71\right)$ was higher than the highest found in the Chesapeake samples $\left(H^{\prime}=2.39\right.$ for the winter upper bay sample) (Zhao et al. 2009). Heterotrophic bacteria in the subarctic area of North Atlantic are known to grow very slowly, even during phytoplankton blooms (Pomeroy \& Deibel 1986), with growth rates as low as 0.002 divisions per day 
Table 1. Characteristics of the samples used in this study and the resulting clone libraries. OTUs: operational taxonomic units

\begin{tabular}{|lcc|}
\hline Parameters $^{\mathrm{a}}$ & July 2007 & December 2008 \\
\hline $\begin{array}{l}\text { Bacterial abundance } \\
\left(\text { cells } \mathrm{ml}^{-1}\right)^{\mathrm{b}}\end{array}$ & $5.4 \times 10^{5}$ & $5.5 \times 10^{5}$ \\
Number of clones & 127 & 45 \\
sequenced & 54 & 10 \\
Number of OTUs & 80 & 93 \\
$\%$ coverage $(C)$ & 3.71 & 1.59 \\
$\begin{array}{l}\text { Shannon-Wiener } \\
\text { index }\left(H^{\prime}\right)\end{array}$ & \\
$\begin{array}{l}\text { aDetails of calculations } \\
\text { methods' section }\end{array}$ & given in the 'Materials and \\
${ }^{\mathrm{b}}$ Coefficient of variation & $18.2 \%$ for July and $13.5 \%$ for \\
December & \\
\hline
\end{tabular}

(reviewed in Rivkin et al. 1996); low temperature (i.e. $<4^{\circ} \mathrm{C}$ ) is thought to be a major environmental factor causing low production by heterotrophic bacteria. It is intriguing to learn that the overall diversity of the Rhodobacterales community, as inferred from $g 5$ gene sequences, in the subarctic coastal water appears higher than that in the temperate estuary. It is known that some Roseobacter bacteria are adapted to cold environments (Brinkhoff et al. 2008). In one study, based on clone library representation, it was estimated that members of the Roseobacter group could make up $>50 \%$ of total bacterial communities in sub-Antarctic waters (Prabagaran et al. 2007), where the annual temperature fluctuation $\left(-1\right.$ to $\left.14^{\circ} \mathrm{C}\right)$ is similar to the Newfoundland coastal water. In Newfoundland, winter water temperatures are low $\left(-1.5\right.$ to $\left.1^{\circ} \mathrm{C}\right)$ while summer temperatures typically reach 14 to $16^{\circ} \mathrm{C}$ in late August and September. This contrasts with Chesapeake Bay, where river flow from the Susquehanna and the other major tributaries (Choptank, Chester, Potomac, James and Rappahannock Rivers) is one of the main environmental forcing factors, leading to a salinity gradient down the estuary, although the annual temperature cycle between $\sim 1$ and $26^{\circ} \mathrm{C}$ cannot be discounted. Another factor that is expected to influence the Rhodobacterales communities is the spring phytoplankton bloom, which typically occurs between late February and late March in the Chesapeake Bay and between mid-April and late May on the east coast of Newfoundland, because the abundance of these bacteria is positively influenced by phytoplankton (Buchan et al. 2005, Rink et al. 2007). A more comprehensive sampling program will be required to validate and address possible reasons for these observations.

A phylogenetic comparison of the sequences from these genes illustrates that some of the sequences we have discovered clearly group with previously described species or strains, while others are more highly divergent, and do not group closely with previously reported GTA capsid sequences (Fig. 1). We found a large number of sequences (10 OTUs, 19 clones), from both summer and winter samples, which cluster with the capsid sequence from Octadecabacter antarcticus, an isolate recovered from sea ice (Gosink et al. 1997). These 10 OTUs were distributed into 4 independent branches within the Octadecabacter clade, suggesting the presence of microdiversity within this group. Similarly, there were 10 OTUs (from 51 clones) that cluster most closely with the sequence from the North Sea bacterium Oceanibulbus indolifex (Wagner-Dobler et al. 2004). These findings provide evidence that organisms closely related to these 2 Roseobacter species may be prevalent in the sub-arctic North Atlantic; sequences that group closely with these species were not recovered from the Chesapeake Bay samples. Another group that appears abundant in our samples, and in the Chesapeake Bay, is related to the genus Loktanella (potentially 12 OTUs from 34 clones); however, the deep branches connecting these sequences are not well supported (Figs. 1 \& S2 in Supplement 1 at www.int-res.com/ articles/suppl/a059p283_app.pdf). We found 2 clone sequences that fall within the Sulfitobacter clade, and our culturing approach recovered isolates in this group (see next section). Where possible, we have grouped multiple clone OTUs into clusters (Fig. 1, labeled 1 to 7 ) that do not show well-supported relationships to any of the known strains/species; there are 3 remaining OTU sequences that are scattered amongst the various Roseobacter groups, again without strongly supported relationships to any of the known strains/species. Another observation is that relatively few sequences were identified in the present study that are closely related to Roseovarius, Phaeobacter, Oceanicola, or Ruegeria strains/species (Fig. 1), most of which have been isolated from more southerly environments.

The previously established congruency between 16S rDNA and g5-based phylogenies (Lang \& Beatty 2007 , Biers et al. 2008) does not necessarily hold true when a subset of the gene information ( $<750$ positions) is used, as demonstrated here. For example, the Rhodobacter capsulatus $g 5$ sequence falls within the Roseobacter group as opposed to grouping with the other Rhodobacter sequences (i.e. R. sphaeroides and Paracoccus denitrificans; Fig. 1). Thus, analysis of the amplified 95 product does not always accurately reflect the expected relationships. This same reasoning presumably explains why some groupings on the g5 phylogenetic tree are not well supported in the bootstrap analysis, especially the deeper branches. However, the $g 5$ marker is still a valuable target for evaluating Rhodobacterales diversity and community 
$\mathrm{NL}$ summer clones NL winter clones $\mathrm{NL}$ isolated strains CB clones

$\mathrm{CB}$ isolated strains

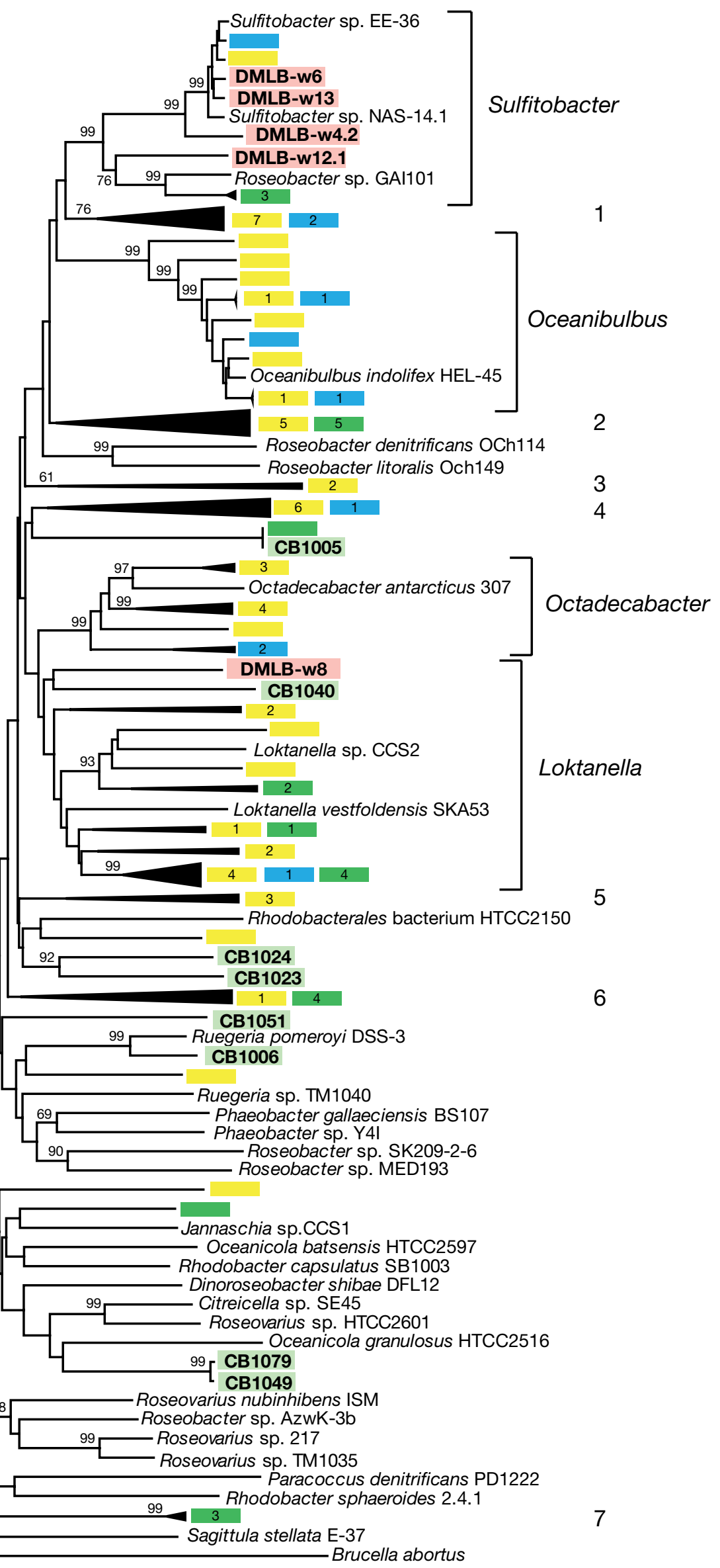


Fig. 1. Phylogenetic tree of gene transfer agent (GTA) capsid gene sequences. Sequences amplified from the western North Atlantic microbial communities in this work are represented by yellow boxes for sequences from July 2007 and blue boxes for sequences from December 2008. Isolates identified in this sudy (DMLB-w4.2, DMLB-w6, DMLB-w8, DMLB-w12.1, and DMLB-w13) are highlighted in pink. Dark green boxes represent sequences from clones and light green boxes represent strains from Chesapeake Bay (Zhao et al. 2009). For simplicity of presentation, some clades that contain only clone sequences are collapsed, and the origins of the sequences in the collapsed clades are indicated using the colors as above. The clusters labelled 1-7 do not show well-supported relationships to any of the known strains/species. Numbers in the boxes represent the number of collapsed operational taxonomic units (OTUs) from each sample; the completely expanded tree with clone sequence identification information is shown in Fig. S2, Supplement 1 (at www.int-res.com/articles/suppl/a059p283_app.pdf). The neighbor-joining tree is based on the aligned nucleotide sequences corresponding to the $g 5$ amplicon ( 747 positions including gaps). Bootstrap values (percentages based on 10000 replicates) are shown for the deepest branch points supported $>60 \%$. Scale bar indicates the number of substitutions per site. The $g 5$ sequence from Brucella abortus was used as the outgroup for the tree. Accession numbers for previously published sequences and pairwise identity values are available in (Table S1, Supplement 1 and in, Supplement 2 (at www.int-res.com/articles/suppl/a059p283_app.xls)

composition because of the ability to amplify these sequences from diverse isolates and uncultured representatives within the order. Furthermore, the currently available evidence indicates that all members of this order contain this gene (Lang \& Beatty 2007, Biers et al. 2008).

Despite the apparent universal GTA cluster conservation in Rhodobacterales genomes and the apparent high abundance of these bacteria in marine communities, GTA genes are generally not prevalent in marine metagenomes, particularly those derived from the Global Ocean Survey (GOS), the most comprehensive survey of marine surface waters to date. As previously suggested, this may be due to metagenome sampling biases or the characterized Rhodobacterales isolates may not be representative of strains found in natural communities (Biers et al. 2008). The latter explanation is not well supported; we have demonstrated here and in previous work (Zhao et al. 2009) an ability to consistently recover novel $g 5$ gene sequences from natural systems. Thus, we support the former explanation, as the overwhelming majority of the GOS samples were processed through $0.8 \mu \mathrm{m}$ filters (Venter et al. 2004, Rusch et al. 2007) that would remove larger, particle-associated or aggregated bacteria and thereby remove many Rhodobacterales. Indeed, a recent analysis of the GOS metagenomic data illustrates this bias (Biers et al. 2009).

\section{Isolation of Roseobacter strains from the western North Atlantic and evaluation of GTA protein expression}

We have cultured 5 independent isolates from the western North Atlantic samples that were identified as belonging to the Rhodobacterales, and specifically within the Roseobacter group (Fig. 2). Four of these (DMLB-w4.2, DMLB-w6, DMLB-w12.1 and DMLBw13) are very closely related to one another and known strains in the Sulfitobacter genus, based on the g5 and 16S rRNA gene sequence information (Figs. 1 \&
2). We also recovered 2 OTUs (representing 5 clones) that group closely with these Sulfitobacter sequences. Sulfitobacter isolates were also common in midAtlantic water during the winter (Zhao et al. 2009). The other isolate (DMLB-w8) falls within the Loktanella clade, based on analysis of $16 \mathrm{~S}$ rDNA sequences (Fig. 2), although this relationship is not strongly supported by the partial $g 5$ sequences (Fig. 1). Our culturing regime used an incubation temperature of $20^{\circ} \mathrm{C}$, which would favor the growth of mesophilic strains and select against psychrophiles. This may explain why we did not recover isolates from the Oceanibulbus or Octadecabacter clades.

We used an antibody that is specific for the GTA capsid protein from Rhodobacterales to examine GTA protein expression in a panel of 12 phylogenetically diverse Rhodobacterales isolates from several different environments (Fig. 3), including the known GTA-producing species Rhodobacter capsulatus and Ruegeria pomeroyi. This is the first application of this tool for examining GTA protein expression. These antibodies allow rapid and accurate assessment of potential GTA production in cultured representatives, and will be invaluable for future studies aimed at studying the regulation of GTA production. The western blots showed that 6 of the other 10 strains we examined showed expression of the GTA capsid protein, and we were able to detect the protein in the supernatants of cultures from 4 of these. Four of the 5 Newfoundland isolates (from the Sulfitobacter clade) showed expression of a GTA protein, and this was detected in the supernatants for 2 of these, DMLB-w12.1 and DMLB-w13 (Fig. 3A). The 3 most closely related Newfoundland strains (DMLB-w4.2, DMLB-w6 and DMLB-w13; Fig. 1) showed 2 positive bands inside the cells, but only the lower of these is the result of a specific reaction with the primary antibody. Two isolates recovered from the Chesapeake Bay (CB1005 and CB1023) also gave positive results for the GTA capsid protein (Fig. 3B). The protein was not detected in Phaeobacter sp. Y4I, Citreicella sp. SE45, or isolates DMLB-w8 and 


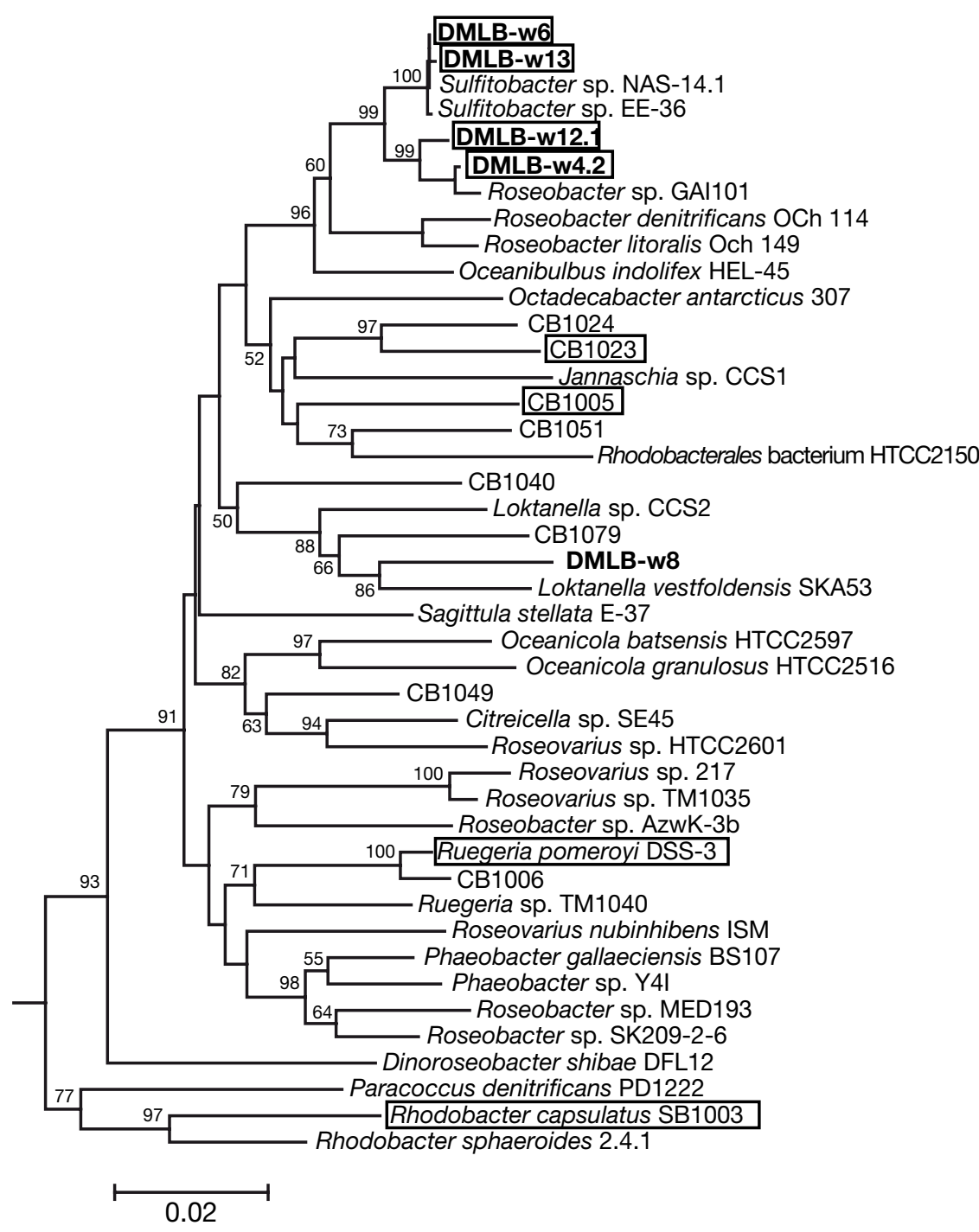

Fig. 2. Phylogenetic relationships of the isolates from this study to other bacteria within the Rhodobacterales. Strains/species that are known to produce GTAs, or believed to produce GTAs based on capsid protein expression, are boxed; isolates from this study are in bold. The neighbor-joining tree is based on partial $16 \mathrm{~S}$ rDNA sequences (1379 positions including gaps), and bootstrap values are shown as percentages based on 10000 replicates for branches supported $>50 \%$. Scale bar indicates the number of substitutions per site. Sequences from outside the Rhodobacterales order were used to root the tree (removed for simplicity). Accession numbers for previously published sequences are provided in Table S1, Supplement 1 (at www.int-res.com/articles/suppl/a059p283_app.pdf)

dependent on growth conditions. It is also possible that these strains may never express the GTA genes. However, it appears that GTA production is a property of bacteria in diverse genera of the Rhodobacterales order (Fig. 2). Work is underway to genetically demonstrate GTA-mediated genetic exchange by these strains.

We conducted peptide-blocking experiments to ensure that we were detecting bands specifically recognized by the antibodies raised against the conserved GTA peptide sequence. We used cell samples from a collection of the Rhodobacterales strains/species and incubated 2 equivalent membranes separately with either the anti-GTA antibody or the anti-GTA antibody that had been pre-incubated with the immunizing peptide. This showed that the bands observed in Rhodobacter capsulatus, DMLBw12.1, Ruegeria pomeroyi DSS-3, and CB1005 are specific (Fig. 3C). One of the 2 bands in DMLB-w6 is specific, while the other is not; close inspection of these lanes shows it is the lower MW band that is specific (Fig. S3, in Supplement 1 at www. int-res.com/articles/suppl/a059p283_ app.pdf).

The Rhodobacter capsulatus major capsid protein is proteolytically cleaved on the C-terminal side of a lysine residue to remove the first 100 amino acids and generate the mature protein found in the RcGTA structure that begins with alanine (Lang \& Beatty 2000). This proteolytic processing was first described in the Escherichia coli phage HK97, where the precursor head protein is also cleaved on the $\mathrm{C}$-terminal side

CB1040, both of which potentially group in the Loktanella clade. The predicted capsid proteins from all these strains contain the immunogenic sequence, and so the lack of detection in these strains could be due to several other reasons. The expression of the protein in the growth conditions used may be below the detection limit for this method in these strains; it is known that the amount of GTA produced by $R$. capsulatus (Solioz et al. 1975) and R. pomeroyi (Biers et al. 2008) is of a lysine, which removes the first 103 amino acids to generate the mature capsid protein that begins with serine (Duda et al. 1995a, Duda et al. 1995b). It is believed this cleavage removes the portion of the capsid protein that acts as a scaffold for head assembly (Duda et al. 1995b). Based on the predicted protein sequence for $R$. capsulatus, this cleavage should produce a mature protein of approximately $31 \mathrm{kDa}$ (Table S2, Supplement 1 at www.int-res.com/articles/ 
A

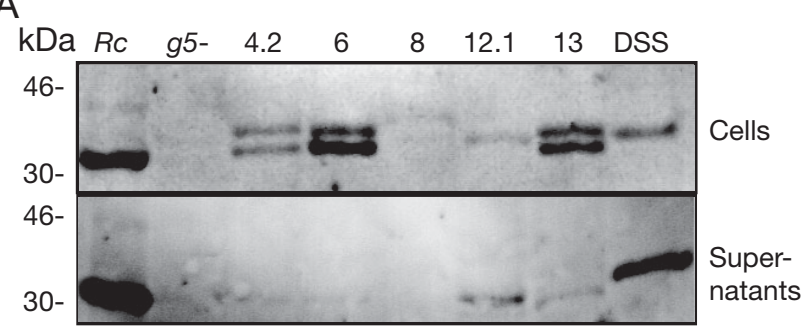

$\mathrm{B}$

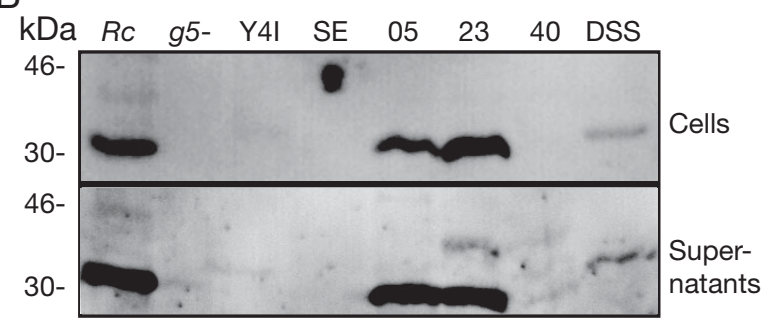

C

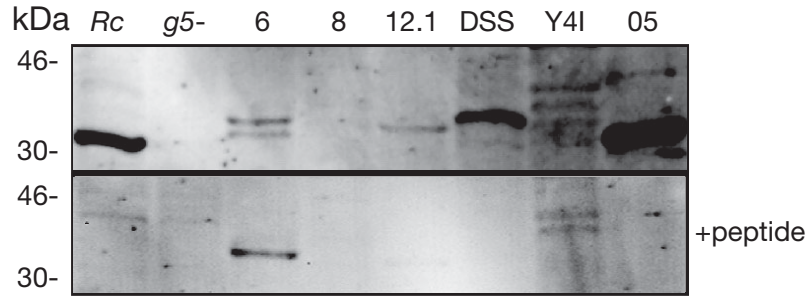

Fig. 3. Expression of gene transfer agent (GTA) capsid proteins in phylogenetically diverse Rhodobacterales bacteria. (A) Expression of GTA capsid proteins in strains isolated from coastal Newfoundland. Top panel shows the results obtained with cells; bottom panel shows the results from the culture supernatants. (B) Expression of GTA capsid proteins in species/strains from other locations. Top panel shows the results obtained with cells; bottom panel shows the results from the culture supernatants. (C) Antibody neutralization experiment demonstrating the specificity of the anti-GTA capsid protein antibodies. Top panel shows the results obtained when the membrane was incubated with the anti-GTA capsid protein antibody; bottom panel shows the results when a duplicate membrane was incubated with the pre-neutralized antibody (+peptide); both panels contain samples of cells from the indicated strains/species. A side-by-side comparison of the full DMLB-w6 lanes is shown in Fig. S3, Supplement 1 (at www.int-res.com/articles/suppl/a059p283_app.pdf). $R C_{\text {, }}$ Rhodobacter capsulatus SB1003; g5-, R. capsulatus A1; 4.2, DMLB-w4.2; 6, DMLB-w6; 8, DMLB-w8; 12.1, DMLBw12.1; 13, DMLB-w13; DSS, Ruegeria pomeroyi DSS-3; Y4I, Phaeobacter sp. Y41; SE, Citreicella sp. SE45; 05, CB1005; 23, CB1023; 40, CB1040. Sizes indicated on the left side correspond to molecular weight standards

suppl/a059p283_app.pdf), and the $R$. capsulatus protein appears as a band of approximately $32 \mathrm{kDa}$ on western blots (Fig. 3). All of the strains/species with positive results showed proteins of very similar size to the $R$. capsulatus protein, between 32 and $34.5 \mathrm{kDa}$ (Fig. 3). An alignment of several capsid protein sequences from species within the Rhodobacterales shows this cleavage site is conserved across all these species, with either an alanine or a serine following the lysine residue (Fig. 4). Therefore, we predict that the other GTA capsid proteins, if produced, would also be processed at this site, and there is a strong congruence between the predicted sizes for mature GTA capsid proteins and the sizes of the proteins detected on the western blots (Table S2; Fig. 3), supporting this prediction. Conservation of this functionally important sequence is another piece of evidence indicating that these GTA genes in different strains/ species are functional. Assaying capsid protein expression in more strains/species with complete genome sequences

and determining the complete $g 5$ sequences for the isolates with detected GTA proteins will allow this to be further confirmed.

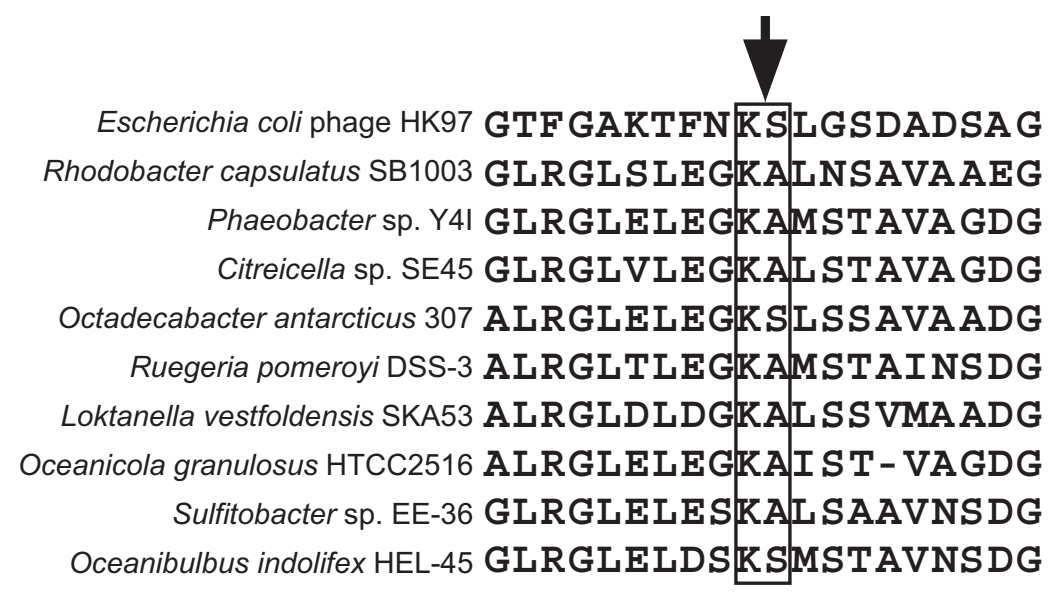

Fig. 4. Conservation of the Escherichia coli phage HK97 and Rhodobacter capsulatus RcGTA capsid protein-processing site in GTA protein sequences. Mature E. coli phage HK97 (Duda et al. 1995b) and R. capsulatus RcGTA (Lang \& Beatty 2000) capsid proteins are proteolytically processed by cleavage on the C-terminal side of a lysine residue, indicated by the arrow. A protein alignment shows this cleavage site is conserved in the GTA capsid proteins from diverse Rhodobacterales species. Accession numbers for the sequences are provided in Table S1, Supplement 1 (at www.int-res.com/articles/suppl/ a059p283_app.pdf) 


\section{SUMMARY}

Despite the prevalence of members of the Rhodobacterales order in diverse marine systems, studies focusing on the biogeographical diversity of order members are limited. This is in part due to the lack of molecular tools that specifically target group members. The GTA g5 gene marker allows us to specifically target the Rhodobacterales community and provides high phylogenetic resolution for this important group of bacteria (Zhao et al. 2009). A remarkable diversity of the Rhodobacterales community was found in the sub-arctic water of the North Atlantic, suggesting that different bacterial species in this group are able to adapt to the cold environment. Our study shows that the genetic diversity of the Rhodobacterales community in the cold Subarctic ecosystem is higher than that in a temperate ecosystem, such as the Chesapeake Bay. The change in the bacterial community structure from warm to cold temperate regions also suggests specific adaptations of Rhodobacterales to different environments. The GTA gene cluster is a conserved genetic trait among this group of bacteria, the production of GTA has been demonstrated in 2 Rhodobacterales, and we have provided evidence that a number of additional strains from multiple locations express the GTA major capsid protein. It now becomes important to determine the rate or frequency of GTA-mediated genetic exchange in natural environments. The abundance of Rhodobacterales and the accumulating evidence of GTA production capacity by species in this order suggest GTA-mediated genetic exchange could be an important mechanism of homologous recombination in natural environments, particularly in marine systems where these bacteria can constitute a large proportion of the heterotrophic microbial community.

Acknowledgements. We thank K. Keats for assisting in sample collection, C. Way for the bacterial abundance data, C. Budinoff for providing the Chesapeake Bay isolates, J. T. Beatty for Rhodobacter capsulatus A1, and D. Campbell for advice on the antibody work. Y.F. and D.M. were supported in part by graduate fellowships from Memorial University of Newfoundland. Research in the laboratories of A.S.L. and R.B.R. was supported by grants from the Natural Sciences and Engineering Research Council (NSERC), the Canada Foundation for Innovation (CFI), and the Industrial Research and Innovation Fund (IRIF) from the Government of Newfoundland and Labrador. Research in the laboratories of A.B. and F.C. is supported by grants from the U.S. National Science Foundation.

\section{LITERATURE CITED}

Bertani G (1999) Transduction-like gene transfer in the methanogen Methanococcus voltae. J Bacteriol 181: 2992-3002
Biers EJ, Wang K, Pennington C, Belas R, Chen F, Moran MA (2008) Occurrence and expression of gene transfer agent genes in marine bacterioplankton. Appl Environ Microbiol 74:2933-2939

Biers EJ, Sun S, Howard EC (2009) Prokaryotic genomes and diversity in surface ocean waters: interrogating the Global Ocean Sampling metagenome. Appl Environ Microbiol 75:2221-2229

Brinkhoff T, Giebel HA, Simon M (2008) Diversity, ecology, and genomics of the Roseobacter clade: a short overview. Arch Microbiol 189:531-539

Brinkmeyer R, Rappe M, Gallacher S, Medlin L (2000) Development of clade (Roseobacter and Alteromonas) and taxon-specific oligonucleotide probes to study interactions between toxic dinoflagellates and their associated bacteria. Eur J Phycol 35:315-329

Buchan A, Gonzalez JM, Moran MA (2005) Overview of the marine Roseobacter lineage. Appl Environ Microbiol 71: 5665-5677

Budinoff C, Hollibaugh J (2007) Ecophysiology of a Mono Lake picocyanobacterium. Limnol Oceanogr 52:2484-2496

Curson ARJ, Rogers R, Todd JD, Brearley CA, Johnston AWB (2008) Molecular genetic analysis of a dimethylsulfoniopropionate lyase that liberates the climate-changing gas dimethylsulfide in several marine $\alpha$-proteobacteria and Rhodobacter sphaeroides. Environ Microbiol 10:757-767

Duda RL, Hempel J, Michel H, Shabanowitz J, Hunt D, Hendrix RW (1995a) Structural transitions during bacteriophage HK97 head assembly. J Mol Biol 247:618-635

> Duda RL, Martincic K, Hendrix RW (1995b) Genetic basis of bacteriophage HK97 prohead assembly. J Mol Biol 247: 636-647

Giovannoni SJ (1991) The polymerase chain reaction. In: Stackebrandt E, Goodfellow M (eds) Nucleic acid techniques in bacterial systematics. John Wiley \& Sons, New York, NY, p 177-201

Gosink JJ, Herwig RP, Staley JT (1997) Octadecabacter arcticus gen. nov., sp. nov., and $O$. antarcticus, sp. nov., nonpigmented, psychrophilic gas vacuolate bacteria from polar sea ice and water. Syst Appl Microbiol 20:356-365

Hammer Ø, Harper DAT, Ryan PD (2001) PAST: paleontological statistics software package for education and data analysis. Palaeontol Electronica 4:1-9

Humphrey SB, Stanton TB, Jensen NS, Zuerner RL (1997) Purification and characterization of VSH-1, a generalized transducing bacteriophage of Serpulina hyodysenteriae. J Bacteriol 179:323-329

> Kan J, Wang K, Chen F (2006) Temporal variation and detection limit of an estuarine bacterioplankton community analyzed by denaturing gradient gel electrophoresis (DGGE). Aquat Microb Ecol 42:7-18

> Lang AS, Beatty JT (2000) Genetic analysis of a bacterial genetic exchange element: the gene transfer agent of Rhodobacter capsulatus. Proc Natl Acad Sci USA 97: 859-864

- Lang AS, Beatty JT (2007) Importance of widespread gene transfer agent genes in $\alpha$-proteobacteria. Trends Microbiol 15:54-62

> Lang AS, Taylor TA, Beatty JT (2002) Evolutionary implications of phylogenetic analyses of the gene transfer agent (GTA) of Rhodobacter capsulatus. J Mol Evol 55:534-543

- Marrs B (1974) Genetic recombination in Rhodopseudomonas capsulata. Proc Natl Acad Sci USA 71:971-973

> Matson EG, Thompson MG, Humphrey SB, Zuerner RL, Stanton TB (2005) Identification of genes of VSH-1, a prophage-like gene transfer agent of Brachyspira hyodysenteriae. J Bacteriol 187:5885-5892 
Moran MA, Belas R, Schell MA, Gonzalez JM and others (2007) Ecological genomics of marine Roseobacters. Appl Environ Microbiol 73:4559-4569

Pomeroy LR, Deibel D (1986) Temperature regulation of bacterial activity during the spring bloom in Newfoundland coastal waters. Science 233:359-361

Prabagaran SR, Manorama R, Delille D, Shivaji S (2007) Predominance of Roseobacter, Sulfitobacter, Glaciecola and Psychrobacter in seawater collected off Ushuaia, Argentina, Sub-Antarctica. FEMS Microbiol Ecol 59:342-355

Rapp BJ, Wall JD (1987) Genetic transfer in Desulfovibrio desulfuricans. Proc Natl Acad Sci USA 84:9128-9130

Ravenschlag K, Sahm K, Pernthaler J, Amann R (1999) High bacterial diversity in permanently cold marine sediments. Appl Environ Microbiol 65:3982-3989

Rink B, Seeberger S, Martens T, Duerselen CD, Simon M, Brinkhoff $\mathrm{T}$ (2007) Effects of phytoplankton bloom in a coastal ecosystem on the composition of bacterial communities. Aquat Microb Ecol 48:47-60

Rivkin RB, Anderson MR, Lajzerowicz C (1996) Microbial processes in cold oceans. I. Relationship between temperature and bacterial growth rate. Aquat Microb Ecol 10: 243-254

Rusch DB, Halpern AL, Sutton G, Heidelberg KB and others (2007) The Sorcerer II global ocean sampling expedition: northwest Atlantic through eastern tropical Pacific. PLoS Biol 5:e77

Saitou N, Nei M (1987) The neighbor-joining method: a new method for reconstructing phylogenetic trees. Mol Biol Evol 4:406-425

Solioz M, Yen HC, Marrs B (1975) Release and uptake of gene

Editorial responsibility: Jed Fuhrman,

Los Angeles, California, USA transfer agent by Rhodopseudomonas capsulata. J Bacteriol 123:651-657

Stanton TB (2007) Prophage-like gene transfer agents-novel mechanisms of gene exchange for Methanococcus, Desulfovibrio, Brachyspira, and Rhodobacter species. Anaerobe 13:43-49

Tamura K, Nei M, Kumar S (2004) Prospects for inferring very large phylogenies by using the neighbor-joining method. Proc Natl Acad Sci USA 101:11030-11035

Tamura K, Dudley J, Nei M, Kumar S (2007) MEGA4: molecular evolutionary genetics analysis (MEGA) software version 4.0. Mol Biol Evol 24:1596-1599

Venter JC, Remington K, Heidelberg JF, Halpern AL and others (2004) Environmental genome shotgun sequencing of the Sargasso Sea. Science 304:66-74

Vos M (2009) Why do bacteria engage in homologous recombination? Trends Microbiol 17:226-232

> Wagner-Dobler I, Rheims H, Felske A, El-Ghezal A and others (2004) Oceanibulbus indolifex gen. nov., sp. nov., a North Sea alphaproteobacterium that produces bioactive metabolites. Int J Syst Evol Microbiol 54:1177-1184

Wall JD, Weaver PF, Gest H (1975) Gene transfer agents, bacteriophages, and bacteriocins of Rhodopseudomonas capsulata. Arch Microbiol 105:217-224

- Yen HC, Marrs B (1976) Map of genes for carotenoid and bacteriochlorophyll biosynthesis in Rhodopseudomonas capsulata. J Bacteriol 126:619-629

Zhao Y, Wang K, Budinoff C, Buchan A, Lang A, Jiao N, Chen F (2009) Gene transfer agent (GTA) genes reveal diverse and dynamic Roseobacter and Rhodobacter populations in the Chesapeake Bay. ISME J 3:364-373

Submitted: September 1, 2009; Accepted: December 22, 2009 Proofs received from author(s): April 12, 2010 